\title{
Molecular immune response of channel catfish immunized with live theronts of
}

\section{Ichthyophthirius multifiliis}

(1)

De-Hai Xu ${ }^{1}$, Qi-Zhong Zhang ${ }^{2}$, Craig A. Shoemaker ${ }^{1}$, Dunhua Zhang ${ }^{1}$ and Gabriel S. A. Moreira $^{3}$

${ }^{1}$ United States Department of Agriculture, Agricultural Research Service, Aquatic Animal Health Research Unit, 990 Wire Road, Auburn, AL 36832-4352, USA

${ }^{2}$ Institute of Hydrobiology, Jinan University, Key Laboratory of Eutrophication and Red Tide Prevention of Guangdong Higher Education Institutes, Guangzhou 510632, PR China. 2

${ }^{3}$ Laboratory of Parasitology, College of Animal Science and Food Engineering, University of Sao Paulo (USP), Av. Duque de Caxias Norte, 225, 13635-900, Pirassununga, SP, Brazil.

6

17

8

9

0

1


22 ABSTRACT: The parasite Ichthyophthirius multifiliis (Ich) has been reported in various

23 freshwater fishes worldwide and results in severe losses to both food and aquarium fish

24 production. The fish surviving natural infections or immunized with live theronts develop strong

25 specific and non-specific immune responses. Little is known about how these immune genes are

26 induced or how they interact and lead to specific immunity against I. multifiliis in channel catfish

27 Ictalurus punctatus. This study evaluated the differential expression of immune-related genes,

28 including immunoglobulin, immune cell receptor, cytokine, complement factor and toll-like

29 receptors in head kidney from channel catfish at different time points after immunization with

30 live theronts of $I$. multifiliis. The immunized fish showed significantly higher anti-Ich antibody

31 expressed as immobilization titer and ELISA titer than those of control fish. The vast majority

32 of immunized fish (95\%) survived theront challenge. Expression of $\operatorname{IgM}$ and $\operatorname{IgD}$ heavy chain

33 genes exhibited a rapid increase from 4 hours (h4) to 2 days (d2) post immunization. Expression

34 of immune cell receptor genes (CD4, CD8- $\alpha$, MHC I, MHC II $\beta$, TcR- $\alpha$, and TcR- $\beta$ ) showed up-

35 regulation from $\mathrm{h} 4$ to $\mathrm{d} 6$ post immunization, indicating that different immune cells were actively

36 involved in cellular immune response. Cytokine gene expression (IL-1 $\beta \mathrm{a}, \mathrm{IL}-1 \beta \mathrm{b}, \mathrm{IFN}-\boldsymbol{\gamma}$ and

37 TNF- $\alpha$ ) increased rapidly at h4 post immunization and were at an up-regulated level until d2

38 compared to the bovine serum albumin control. Expression of complement factor and toll-like

39 receptor genes exhibited a rapid increase from h4 to d2 post immunization. Results of this study

40 demonstrated differential expression of genes involved in the specific or non-specific immune

41 response post immunization and that the vaccination against Ich resulted in protection against

42 infection by I. multifiliis.

43 
44 Keywords: Immunization; serum antibody; survival; channel catfish; Ichthyophthirius multifiliis

45 Immune-related genes; qPCR

\section{1. Introduction}

48 Ichthyophthiriasis caused by the parasite Ichthyophthirius multifiliis (Ich) has been reported in

49 various freshwater fishes worldwide and results in severe losses to both food and ornamental fish

50 production $[1,2]$. In the US, $42 \%$ producers of channel catfish Ictalurus punctatus suffered more

51 than $2000 \mathrm{lb}$ losses per producer due to the parasite in 2002 [3,4], and Ich infections in fingerling

52 fish affected close to four percent of total channel catfish producers in 2009 [5]. The life cycle of

53 the parasite includes 3 stages: an infective theront, a parasitic trophont and a reproductive tomont

$54[1,2]$. There are some treatments or combinations of treatments available for the parasite [1].

55 However, it is difficult to control the parasite using chemotherapy after its theront penetrates into 56 fish skin and gills [6].

57 Immune protection has been successfully demonstrated in fish surviving natural and 58 experimental Ich infections or following immunization with Ich antigens $[1,7,8,9]$. To date, one

59 of the most effective ways to immunize against Ich is by intraperitoneal (IP) injection of live

60 theronts. The fish immunized with live theronts developed strong specific and non-specific

61 immune responses $[8,9,10]$. Both systemic and mucosal immune responses are involved in

62 protection against I. multifiliis $[9,11,12]$. Systemic and mucosal antibodies were demonstrated to 63 agglutinate the parasites in vitro [7,9,10]. There are three major types of immunoglobulins in 64 teleost fish: $\operatorname{IgM}, \operatorname{IgD}$ and $\operatorname{IgT} / \operatorname{IgZ}$, but only $\operatorname{IgM}$ and $\operatorname{IgD}$ have been identified in channel catfish $65[13,14,15]$. IgD includes a membrane bound form (IgD2) and a secreted form (IgD3) [13]. 
66 Functions of IgD in immune responses are largely unknown and need further study. The fish

67 infected with theronts also induced localized cellular infiltration, including lymphocytes,

68 granulocytes and macrophages $[10,16]$.

69 Sigh et al. [12] detected an increase in gene expression of IgM, major histocompatibility

70 complex (MHC) and complement component $\mathrm{C} 3$ in rainbow trout after exposure to Ich. In a

71 study of the initial response of rainbow trout fry to infection with I. multifiliis, Heinecke and

72 Buchmann [17] found that IL-1 $\beta$, IL-6, and IL-8 were up-regulated after fish were exposed to the

73 Ich theronts. Von Gersdorff Jørgensen et al. [18] found that complement factors C3, C5 and

74 factor B were up-regulated in liver and head kidney of rainbow trout following immunization

75 with a live vaccine against Ich. Olsen et al. [15] also noted that significant up-regulation of genes

76 encoding IgM, IgT, C3, and IFN- $\gamma$ were induced by immunization with Ich theronts in rainbow

77 trout. The gene expressions of toll-like receptors TLR-1 and TLR-2 were observed to be

78 significantly up-regulated in the head kidney of channel catfish after infection by Ich [19]. Little

79 is known about how these immune genes are induced, how they interact and how they lead to

80 specific immunity against $I$. multifiliis in channel catfish. The objective of this study was to

81 evaluate molecular immune response and investigate differential expression of immune-related

82 genes in head kidney from channel catfish over a time course after immunization with live

83 theronts of I. multifiliis.

84

85 2. Materials and methods

$86 \quad 2.1$ Fish and parasite

87 Channel catfish (Industry pool strain) were obtained from disease-free stock from the USDA-

88 ARS Catfish Genetic Research Unit, Stoneville, MS and reared to experimental size in indoor 
89 tanks at the USDA, Aquatic Animal Health Research Unit, Auburn, AL. Ichthyophthirius

90 multifiliis (ARS 15 strain) originally isolated from infected tropical pet fish was maintained by

91 serial transmission on channel catfish held in 50-1 glass aquaria as described by Xu et al. [9].

92

$93 \quad 2.2$ Water quality

94 Dissolved oxygen (DO) and temperature were measured using an YSI 85 oxygen meter (Yellow

95 Springs Instrument, Yellow Springs, $\mathrm{OH})$. The $\mathrm{pH}$, hardness, ammonia and nitrite were

96 determined using Hach CEL/890 Advanced Portable Laboratory (Loveland, CO). During the

97 trial, a light:dark period of 12:12 h was maintained and supplemental aeration was supplied by

98 air stones. The water quality was measured daily throughout the trial and expressed as mean \pm

99 standard error: dissolved oxygen $5.8 \pm 0.4 \mathrm{mg}^{-1}, \mathrm{pH} 7.0 \pm 0.2$, ammonia $0.27 \pm 0.3 \mathrm{mg}^{-1}$,

100 hardness $95.5 \pm 7.9 \mathrm{mg} \mathrm{l}^{-1}$, nitrite concentration below detectable level and water temperature

$10122.1 \pm 0.4^{\circ} \mathrm{C}$, measured daily. All water parameters were within acceptable levels for catfish.

102

$103 \quad 2.3$ Theront preparations

104 Fish heavily infected with mature trophonts were anesthetized with $300 \mathrm{mg} \mathrm{l}^{-1}$ tricaine

105 methanesulfonate (MS 222), rinsed with water and the skin was gently scraped to dislodge the

106 parasites. Trophonts were harvested by filtering through a $0.45 \mu \mathrm{m}$ filter to remove fish skin.

107 The isolated trophonts were placed in Petri dishes and allowed to attach. After replacing the

108 water in the Petri dishes with fresh dechlorinated water to remove contaminating mucus,

109 trophonts were incubated for $18 \mathrm{~h}$ at $24^{\circ} \mathrm{C}$. Theronts were harvested by pouring through a sieve

110 with a pore size of 22 microns. For IP injection, theronts were concentrated by centrifugation at 
$111100 \times g$ for $3 \mathrm{~min}$ and suspended in phosphate-buffered saline ( $\mathrm{pH}$ 7.2, PBS). Theronts were

112 counted in five $10 \mu \mathrm{l}$ samples of theront solution with the aid of a Sedgewick-Rafter cell, where

113 average counts were used for concentration calculation. A 5\% bovine serum albumin (BSA;

114 Sigma Chemical Co., St. Louis, MO) solution was prepared in PBS to be used in the mock-

115 immunized control.

116

1172.4 Experimental design and immunization procedure

118 A total of 110 channel catfish with an average length of $15.1 \pm 1.3 \mathrm{~cm}$ (mean $\pm \mathrm{SEM})$ and weight

119 of $30.1 \pm 7.2 \mathrm{~g}$ were used in this trial. All fish treatment protocols were approved by Institutional

120 Animal Care and Use Committee at the Aquatic Animal Health Research Unit. Ten catfish were

121 sampled to verify that the fish were free from parasites and detectable serum antibody against Ich

122 prior to initiation of the trial. All fish were negative for Ich infection (i.e. no visible attached

123 theronts under microscopy) and no anti-Ich antibody was detected in fish serum prior to study.

124 Fish were then distributed into 4 replicated groups and immunized by IP injection as follows:

125 groups 1 and 3 with live theronts at a dose of 15,000 theronts ( $0.1 \mathrm{ml}$ in volume) per fish; groups

1262 and 4 with $0.1 \mathrm{ml}$ of 5\% BSA as mock-immune control. There were 15 fish per tank in the

127 groups 1 (immune) and 2 (control) to collect tissues for immune gene expression analysis. There

128 were 10 fish per tank in groups 3 (immune) and 4 (control) to evaluate immune protection and

129 fish survival 21 days post immunization.

130

1312.5 . Blood and tissue sampling

132 Five fish were sampled from groups 1 and 2 at h4 (4 hours), d1 (1 day), d2, d6, d10 and d20

133 post immunization to collect serum for measuring antibody and tissues for evaluating immune 
134 related genes. The blood was collected after fish were anesthetized with $100 \mathrm{mg} \mathrm{l}^{-1}$ MS-222.

135 After blood collection, fish were euthanized by $300 \mathrm{mg} \mathrm{l}^{-1}$ MS-222 and head kidney was

136 collected and immediately immersed in RNAlater (Invitrogen, Carlsbad, CA). All samples were

137 incubated overnight at $4{ }^{\circ} \mathrm{C}$ and then transferred to $-20^{\circ} \mathrm{C}$ until RNA extraction.

139 2.6. Anti-Ich antibodies in serum of channel catfish

140 Serum anti-Ich antibodies were determined by both theront immobilization assay and enzyme-

141 linked immunosorbent assay (ELISA). The immobilization assay was conducted by placing

142 theronts in serum serially diluted in 96 well flat bottomed microtitre plates (Corning Costar,

143 Corning, NY) as described by Xu et al. [9]. A solution of 50\% (v:v) PBS diluted with tank water

144 was used as a diluent. Immobilization titer was the inverse of the highest dilution of serum in

145 which all theronts were immobilized. Anti-Ich antibodies were measured in two replicates for

146 each serum sample with ELISA as described by Xu et al. [20]. An optical density (OD) reading

147 in a sample from experimental fish was considered positive when its value was two times greater

148 than the OD readings in the control. The ELISA titer was the inverse of the highest dilution of

149 serum in which a sample was positive.

$151 \quad 2.7$ Challenge and parasite infection level

152 At d21 post immunization, fish in groups 3 and 4 were exposed to 40,000 theronts per fish for 1

$153 \mathrm{~h}$ with aeration after tank water was lowered to $10 \mathrm{~L}$ in each tank. Water flow $\left(0.5 \mathrm{~L} \mathrm{~min}^{-1}\right)$ was

154 resumed at $1 \mathrm{~h}$ post exposure and the fish were monitored for Ich infection and mortality for 3

155 weeks after theront challenge. Five days post theront challenge, numbers of white spots on the 
156 body surface of each fish were counted as described previously [9]. The infection levels were

157 evaluated using a semi-quantitative scale: no infection $\left(0\right.$ trophonts fish $\left.{ }^{-1}\right)$, light infection $(<50$

158 trophonts fish $\left.{ }^{-1}\right)$, mild infection (50-100 trophonts fish ${ }^{-1}$ ) and heavy infection (>100 trophonts

159 fish $\left.^{-1}\right)$.

160

1612.8 Total RNA extraction and cDNA synthesis

162 Total RNA from head kidney tissue was extracted using TRIzol Reagent (Invitrogen, Carlsbad,

163 CA) following the manufacturer's protocol. The isolated RNA samples were treated with DNase

164 (Life Technologies, Carlsbad, CA) to minimize contamination of genomic DNA. Quantity and

165 quality of RNA samples were determined on a Nanodrop ND-1000 spectrophotometer

166 (Nanodrop Technologies, Rockland, DE) and by electrophoresis on 1.0\% agarose gel. The first

167 strand cDNAs used for quantitative PCR were synthesized using $2 \mu \mathrm{g}$ of total RNA, AMV

168 reverse transcriptase, and Oligo-dT primer provided by the cloned AMV first strand cDNA

169 synthesis kit (Invitrogen).

170

1712.9 Primer design and quantitative PCR

172 Sixteen immune related genes were selected in this study based on published reports of immune

173 genes affected by parasite and bacterial infection, including genes of immunoglobulin, immune

174 cell receptor, cytokine, complement factor and toll-like receptor $[18,19,21,22,23]$. The gene-

175 specific primers were designed with the aid of Primer3

176 (http://biotools.umassmed.edu/bioapps/primer3_www.cgi) and are listed in Table 1. Channel

177 catfish $18 \mathrm{~S}$ ribosomal RNA gene primers [23] were included as an internal calibrator to normalize 
178 cDNA quantities. Primers for immune genes were synthesized by Sigma Aldrich (St. Louis, MO).

179 Quantitative PCR (qPCR) was performed in triplicate for each cDNA sample in MicroAmp ${ }^{\circledR}$

180 Optical 96-well reaction plates (Applied Biosystems, Foster City, CA) using Applied Biosystems

181 (ABI)7500 Real-Time PCR System. All qPCR reactions were performed using Platinum ${ }^{\circledR} \mathrm{SYBR}^{\circledR}$

182 Green qPCR SuperMix-UDG with ROX (Invitrogen) in a total volume of $12 \mu \mathrm{l}$. The qPCR

183 mixture consisted of $0.5 \mu \mathrm{l}$ of cDNA (input RNA of $5 \mathrm{ng}$ ), $1 \mu \mathrm{l}$ of $5 \mu \mathrm{M}$ gene-specific forward

184 primer, $1 \mu \mathrm{l}$ of $5 \mu \mathrm{M}$ gene-specific reverse primer, $6 \mu 1$ of $2 \times$ SYBR Green SuperMix and $3.5 \mu 1$

185 of DEPC-treated water. The qPCR thermal cycling parameters were $50{ }^{\circ} \mathrm{C}$ for 2 min, $95^{\circ} \mathrm{C}$ for 2

$186 \mathrm{~min}$ followed by 40 cycles of $95^{\circ} \mathrm{C}$ for $15 \mathrm{~s}$ and $60^{\circ} \mathrm{C}$ for $1 \mathrm{~min}$. Specificity of amplified products

187 was assessed using melting curve analysis (ABI 7500 Real-time PCR Software V2.0) and by gel

188 electrophoresis using separate end-point PCR reactions. The PCR products were also gel-excised,

189 purified and sequenced to confirm that they match target gene sequences. Primer efficiency was

190 set ranging from $90-100 \%$ calculated using $E=\left(10^{\wedge}(-1 /\right.$ slope $\left.)-1\right) * 100$ and a primer pair would be

191 redesigned if it did not meet the requirement.

192

193

\subsection{Data analysis}

194 The relative transcriptional levels of different genes were determined by subtracting the cycle

195 threshold $(\mathrm{Ct})$ of the sample by that of the $18 \mathrm{~S}$ ribosomal RNA, the calibrator, using the formula:

$196 \Delta \mathrm{Ct}=\mathrm{Ct}$ (sample) $-\mathrm{Ct}$ (calibrator). The relative expression level of a specific gene in theront

197 immunized fish was compared to that of mock-immunized fish to obtain $2^{\Delta \Delta \mathrm{Ct}}$, where $\Delta \Delta \mathrm{Ct}=$

$198 \Delta \mathrm{Ct}$ (control) $-\Delta \mathrm{Ct}$ (immune) described by Pfaffl [24]. All data were analyzed with SAS

199 software [25]. Mean days to death (MDD) were calculated by the Lifetest procedure (Kaplan-

200 Meier method). Serum antibody titers from different immunized groups were analyzed with 
201 Duncan's multiple range test. Probabilities of 0.05 or less were considered statistically

202 significant.

203

\section{3. Results}

2053.1 Effects of theront immunization on anti-Ich antibody responses

206 The ELISA titers of anti-Ich antibodies between control fish and fish immunized with live

207 theronts at d6 or less post immunization did not differ (Table 2). Fish serum antibodies

208 increased significantly in immune fish at d10 post immunization. Serum anti-Ich antibodies were

20964 fold higher in immobilization titer or 115 fold higher in ELISA titer in immune fish than

210 control fish at d20 post immunization (Table 2).

2123.2 Effects of theront immunization on catfish infection and survival

213 Immunization with live theronts did not completely prevent theront re-infection. At d6 post

214 challenge, the fish immunized with live theronts had light infection $\left(<50\right.$ trophonts fish ${ }^{-1}$, Table

215 3). Fish of non-immunized control showed heavy infection with more than 100 trophonts fish ${ }^{-1}$.

216 All mock-immunized control fish died from Ich challenge with MDD of 5.6 day. Immunization

217 with live theronts by IP injection provided good protection and 95\% of fish survived theront

218 challenge (Table 3).

219

220

\subsection{Expression of immunoglobulin genes}

221 Expression of $\operatorname{IgM}$ and $\operatorname{IgD}$ heavy chain genes exhibited a pattern of rapid increase in expression 222 from $\mathrm{h} 4$ to $\mathrm{d} 2$ post immunization then a drop to a lower level of expression in the immunized fish 223 compared to BSA control (Fig 1). The membrane bound form of $\operatorname{IgD}(\operatorname{IgD} 2)$ gene in the 
224 immunized fish showed similar expression pattern as IgM gene after fish immunization. The

225 secreted form of $\operatorname{IgD}(\operatorname{IgD} 3)$ gene showed different expression pattern compared to IgM gene.

226 The IgD3 gene in the immunized fish showed a down-regulation from d1 to d20 post

227 immunization (Fig 1).

228

2293.4 Expression of immune cell receptor genes

230 The CD4 and CD8- $\alpha$ gene expression increased rapidly at h4 post immunization by 7 -fold,

231 peaked at d1 (7-17 fold) and remained at high level until d6 post immunization compared to the

232 mock immunized control (Fig 2). CD4 and CD8- $\alpha$ were also the only two among immune cell

233 receptor genes that displayed down-regulation at one time-point throughout the trial at d10 post-

234 immunization. The MHC I, MHC II $\beta$, TcR- $\alpha$, and TcR- $\beta$ genes showed up-regulation from $\mathrm{h} 4$ to

235 d20 post immunization. The gene expression was 3 -fold or higher in immunized fish from $\mathrm{h} 4$ to

$236 \mathrm{~d} 1$, then remained at high level until d20. Among them, MHC I showed the highest expression,

237 5-11 fold higher from $\mathrm{h} 4$ to $\mathrm{d} 6 \mathrm{in}$ immunized fish than control. The kinetics of TcR- $\alpha$ expression

238 was similar to that of TcR- $\beta$ and peaked at $\mathrm{d} 2$ post immunization. The TcR- $\alpha$, however,

239 exhibited a higher upregulated expression (3-6 fold) than control fish compared to TcR- $\beta$ in

240 immunized fish (Fig 2).

$243 \quad 3.5$ Expression of cytokine genes

244 All cytokine genes increased rapidly at $\mathrm{h} 4$ post immunization and were up-regulated until $\mathrm{d} 2$

245 compared to the control (Fig 3). These 4 cytokine genes showed 7-22 fold increase in immunized

246 fish compared to those of control at h4 post immunization. The expression levels of IL-1ßa, IL- 
$2471 \beta \mathrm{b}$ and IFN- $\gamma$ were then decreased in immunized fish after d6 post immunization. TNF- $\alpha$

248 expression, however, remained at a higher level in immunized fish during the trial from h4 to

249 d20 post immunization (Fig 3).

2513.6 Expression of complement factor and toll-like receptor genes

252

253 The complement component 3 (C3) gene increased rapidly to 15 fold in immunized fish

254 compared to the level of control at h4 post immunization (Fig 4). The expression level

255 maintained at least 3 fold higher than control during the entire trial. Complement factor D

256 (CFD), TLR-1 and TLR-9 exhibited a rapid increase in expression from h4 to d2 post

257 immunization then a drop to lower levels in immunized fish at d6 post immunization compared

258 to BSA control.

\section{4. Discussion}

261 Previous studies demonstrated that both humoral and cellular immune responses are involved in

262 protection of fish against Ich $[2,4,9,16]$. In this study, antibodies against Ich were detected in

263 serum of immunized fish d6 post immunization by both ELISA and immobilization assays. Anti-

264 Ich antibody level was significantly increased from d10 post immunization to d20 of the trial.

265 The increase of anti-Ich antibody was in agreement with previous studies. Xu et al. [9,20] found

266 that serum antibodies in immunized fish were 37-56 fold higher than that of control fish d12 post

267 immunization. Gene expression of $\operatorname{IgM}$ and $\operatorname{IgD}$ heavy chain exhibited a different pattern

268 compared to antibody production (as measured via ELISA and immobilization titer). IgM and

269 IgD heavy chain mRNAs were rapidly induced from h4 to $\mathrm{d} 2$ post immunization with a 
270 subsequent drop in expression in the immunized fish. Although genes encoding immunoglobulin

271 heavy chains showed rapid mRNA up-regulation for a short period of time, anti-Ich antibodies

272 increased slowly reaching high levels at d20 post immunization, anti-Ich antibodies were 115

273 fold higher measured with ELISA (titer 1152) and 64 fold higher by immobilization assay (titer

274 1280) in immunized fish than that of control fish. Antibody formation includes multiple steps

275 from gene expression to protein production. One would expect a time difference between the

276 upregulation of immunoglobulin genes to the production of functional antibody. Once antigen is

277 presented to the B-cell, the B-cell undergoes several steps prior to proliferation and

278 differentiation for antibody production (i.e., plasma cell). In most cases antibody levels reach a

279 peak 7-10 days post immunization but this time line can vary dependent on the antigen [26]. The

280 duration from Ig gene expression to antibody production is also probably affected by fish species

281 and water temperature. The immunized fish achieved 95\% survival after challenge with live Ich

282 theronts. In previous studies in catfish, host protection was also demonstrated in fish immunized

283 with live theronts by IP injection, which lead to $93-100 \%$ fish survival $[9,20]$. In a study in

284 rainbow trout [18], the gene encoding IgM was weakly up-regulated 24h following

285 immunization with a live vaccine against Ich in the head kidney. In the same trial, anti-Ich

286 antibody was detected at a low level (titer 25) in the rainbow trout plasma using a modified

287 ELISA 4 week post immunization. The work suggests a positive correlation between expression 288 of immunoglobulin genes and production of antibodies against the parasite.

289 Channel catfish express two Ig isotypes: $\operatorname{IgM}$ and $\operatorname{IgD}$. No $\operatorname{IgT} / \operatorname{IgZ}$ reported in trout and carp

290 (Cyprinus carpio L.) $[4,14]$ has been identified in catfish. Catfish IgM has been extensively

291 studied at the functional and structural levels [27]. In contrast, much less is known about the 
292 teleost IgD [13]. IgD presents on the surface of B-lymphocytes in either a membrane-bound form 293 (IgD2) or in blood serum as a secreted form (IgD3) [13]. When a B-cell reaches its mature state, 294 it co-expresses both $\operatorname{IgM}$ and $\operatorname{IgD}$. $\operatorname{IgD}$ is able to signal B-cells causing activation of the immune 295 system [28]. In this study, specific primers ( $\operatorname{IgD})$ were designed to target both membrane bound 296 form (AF363448) and secreted form (AF363450) of IgD heavy chain gene of channel catfish 297 [13]. The primers for IgD2 are specific for targeting only the membrane bound form of $\operatorname{IgD}$ and $298 \operatorname{IgD} 3$ specific only to the secreted form of $\operatorname{IgD}$. The gene expression pattern was similar between 299 total $\operatorname{IgD}$ and the membrane-bound form of $\operatorname{IgD}(\operatorname{IgD} 2)$. However, the expression pattern was 300 slightly different between IgM and IgD. Expression of IgM in the immunized fish increased 301 rapidly and reached its peak at $\mathrm{h} 4$ post immunization and then gradually decreased. $\operatorname{IgD}$ 302 expression increased and reached its peak at d1 post immunization with a gradual decrease 303 thereafter. The up-regulation of $\operatorname{IgM}$ and $\operatorname{IgD}$ indicates that both $\operatorname{IgM}$ and $\operatorname{IgD}$ of catfish can be 304 induced by theront immunization and may play an active role in humoral immune response.

305 Similar up-regulation of IgM gene was also noted in rainbow trout. Sigh et al [12] reported that 306 Ich infection induced up-regulation of the IgM gene in the head kidney of rainbow trout as early 307 as 4 days and kept significantly higher level d26 post infection. Ich induced production of 308 antibodies in both the skin and head kidney [12].

309 Cell-mediated immune responses are executed by leukocytes, granulocytes, macrophages 310 (monocytes), dendritic cells and lymphocytes [29]. In the early stages of Ich infection, the 311 neutrophil was identified as the predominant cell type in carp [16]. When the trophont develops, 312 cells migrating toward the infection sites show increase numbers of macrophages, neutrophils 313 and resident epidermal filament cells [16]. Dan et al. [30] recently evaluated cellular immune 
314 response by measuring respiratory burst activity of leukocytes in orange-spotted grouper

315 (Epinephelus coioides) after immunization with Cryptocaryon irritans vaccine. Cryptocaryon

316 irritans is an obligate parasite of tropical and subtropical marine fish that causes white spot

317 disease similar to I. multifiliis in freshwater. The results revealed that respiratory burst activity

318 of leukocytes was significantly higher in fish after immunization with the high-dose $(30,000$

319 theronts fish $\left.{ }^{-1}\right)$ of $C$. irritans vaccine than fish immunized with low-dose $\left(10,000\right.$ theronts fish $\left.{ }^{-1}\right)$

320 vaccine or with PBS control. The increased activity of respiratory burst activity in the immune

321 fish may be due to the increased number of leukocytes involved in the cellular immune response

322 [29]. Genes of MHC I, MHC II $\beta$, CD4 (cluster of differentiation 4) and CD8- $\alpha$ encoded

323 glycoproteins expressed on the immune cell surface or served as co-receptors of immune cells

324 [31]. All immune cell receptor genes examined in this study were up-regulated h4 post

325 immunization with live theronts and levels remained high for 6 days or longer post

326 immunization. Results in this study indicated that different immune cells were actively involved

327 in cellular immune response. In a previous study, Sigh et al [12] reported that MHC II $\beta$ gene

328 was significantly up-regulated in the head kidney of rainbow trout from $\mathrm{d} 4$ to d26 post infection

329 by I. multifiliis.

$330 \quad$ Interleukins (ILs) and interferons (IFNs) are a group of small proteins that belong to

331 cytokines and produced by macrophages, lymphocytes, granulocytes, or epithelial cells [31].

332 Cytokines are secreted by activated immune-related cells upon induction by various pathogens,

333 such as parasitic, bacterial, or viral components and modulate the balance between humoral and

334 cellular immune responses [32]. In this study, cytokine genes showed up-regulation in

335 immunized fish from $\mathrm{h} 4$ to $\mathrm{d} 2$ post immunization. Heinecke and Buchmann [17] studied the 
336 immune responses of rainbow trout to an infection with I. multifiliis and found that IL-1 $\beta$ was

337 up-regulated $3 \mathrm{~h}$ post infection and kept up-regulation during the $72 \mathrm{~h}$ experiment with a peak at

$33812 \mathrm{~h}$ post infection. Their result indicates that IL-1 $\beta$ is an initiator of the inflammatory response

339 in rainbow trout infected with I. multifiliis. In a study to evaluate inflammatory responses caused

340 by I. multifiliis in carp, Gonzalez et al. [33] reported that the expression levels of IL-1 $\beta$ reached a

341 maximum of a 150 -fold increase at $36 \mathrm{~h}$ post infection, and remained significantly elevated (18

342 fold) as compared to the uninfected controls. They also reported a significant up-regulation of

343 cytokine TNF- $\alpha$ at 36 and $48 \mathrm{~h}$ post infection (3- and 4-fold increase respectively). Results in

344 this study and previous studies by other researchers indicate a rapid involvement of cytokine

345 genes in the innate immune response.

346 The complement system is a part of the innate immune system that helps antibodies and

347 phagocytic cells to clear pathogens from host. Complement-mediated killing occurs when

348 complement is activated either directly by pathogen components and/or by antibody-antigen

349 complexes [33]. In this study, the expression of complement factor 3 was 4-15 fold higher in the

350 immunized fish than control fish. Complement factor 3 showed upregulation in immunized fish

351 from h4 to d20 post immunization, indicating a rapid and active involvement of innate immune

352 response. In a similar study to evaluate immune gene expression in rainbow trout following

353 immunization with live vaccine against I. multifiliis, Jørgensen et al. [18] reported that the

354 complement factors C3 (9-fold) and C5 (21-fold) were up-regulated in the head kidney $24 \mathrm{~h}$ post

355 immunization. Sigh et al. [12] also noted an up to 5-fold increase in C3 gene expression at d 4-6

356 in the skin and d 6-26 in the spleen, indicating that the complement system is also contributing to

357 the immune reactions against I. multifiliis in rainbow trout. 
Toll-like receptors are important activators of innate immunity by recognition of conserved pathogen-associated ligands [19,35]. TLR-1 is expressed on cell surfaces and recognize mainly microbial membrane components while TLR-9 expressed exclusively in intracellular vesicles to recognize microbial nucleic acids [35]. In this study, both TLR-1 and TLR-9 showed an early up-regulation at $\mathrm{h} 4$, peak of expression at $\mathrm{d} 1$ and then down-regulation at d6. In a study with

363 channel catfish infected with Ich theronts, Zhao et al [19] observed an up-regulation of gene

364 TLR-1 at h12, the peak at $\mathrm{d} 3$ and down-regulation at d7 in the head kidney. In the same study,

365 TLR9 was numerically up-regulated from h6 to d1 post infection. Results in this study and

366 previous report [19] demonstrated that TLR1 and TLR9 genes were involved in the early

367 immune response against Ich infection.

368 When live theronts were IP injected into fish, the theronts can survive within peritoneal 369 cavity from several days to 3 weeks [36]. The theronts attach to fish tissues and damage fish 370 tissues by its constant rotation, shape transformation and site relocation [37]. The invasion of

371 theronts and tissue damage in fish initiates informatory response and cellular immune response

$372[4,15,16]$. Then the GPI-anchored surface membrane proteins and secreted products from the

373 attached trophonts stimulates humoral immune response [4,9]. It seems that immune response is

374 initiated locally at the site of infection and as the infection progress it becomes systemic [12].

375 The anterior kidney and spleen are the central systemic sites of adaptive immunity against $I$.

376 multifiliis [4]. In this study, we mainly focused on the expression of genes related to innate and 377 adaptive immune responses in systemic immunity. Results in this study demonstrate that $I$.

378 multifiliis vaccination improves innate and adaptive immune responses in catfish and enhance 379 fish anti-parasite resistance. 


\section{Conclusion}

382 This study evaluated immune response and expression of immune-related genes in head

383 kidney from channel catfish after immunization with live theronts of I. multifiliis. The

384 immunized catfish showed significantly higher antibody titers than those of mock immunized

385 fish and $95 \%$ of immunized fish survived theront challenge. Results of this study demonstrated

386 differential expression of genes involved in the specific or non-specific immune response post

387 immunization and that the vaccination against Ich resulted in protection against infection by $I$.

388 multifiliis. Results of this study may allow for development of alternative control strategies for

389 Ich by leading to a better understanding of the immune response of catfish to this parasite.

\section{Acknowledgments}

392 The authors thank Dr. Jason Abernathy, USDA-ARS, Hagerman Fish Culture Experiment 393 Station, Hagerman and Dr. Xing-Jiang Mu, College of Fisheries and Life Science, Shanghai

394 Ocean University for valuable comments and suggestions to improve the manuscript. We 395 gratefully acknowledge the technical assistance of Jana Mladek, Paige Mumma and the 396 management team of the Aquatic Animal Health Research Unit aquatic facility for daily care 397 and management of fish. We are also grateful to the FAPESP for providing a scholarship to 398 Gabriel S. A. Moreira (Proc. no. 2015/01822-0). This research was supported by USDA/ARS 399 CRIS Project \#6010-32000-026-00D. Mention of trade names or commercial products in this 400 publication is solely for the purpose of providing specific information and does not imply 401 recommendation or endorsement by the US Department of Agriculture. 


\section{References:}

404 [1] H.W. Dickerson, D.L. Dawe, Ichthyophthirius multifiliis and Cryptocaryon irritans 405 (Phylum Ciliophora), in: P. Woo, Fish Diseases and Disorders, CAB International, 406 Wallingford, 1995, pp. 181-227.

407 [2] R.V. Matthews, RA Ichthyophthirius multifiliis Fouquet and ichthyophthiriosis in 408 freshwater teleosts. Adv. Parasitol. 59 (2005) 159-241.

409 [3] T.R. Hanson, S. Shaik, K.H. Coble, S. Edwards, J.C. Miller, Identifying risk factors 410 affecting weather-and disease-related losses in the U.S. farm-raised catfish industry, Agric.

411 Resour. Econ. Rev. 37 (2008) 27-40.

412 [4] H.W. Dickerson, R.C. Findly, Immunity to Ichthyophthirius infections in fish: A synopsis. 413 Developmental \& Comparative Immunology 43 (2014) 290-299.

414 [5] USDA, Catfish 2010 Part III: Changes in Catfish Health and Production Practices in the 415 United States, 2002-2009. USDA-APHIS-VS-CEAH-NAHMS, 2010.

416 https://www.aphis.usda.gov/animal_health/nahms/aquaculture/downloads/catfish10/Cat10_ 417 dr_PartIII.pdf.

418 [6] M. Tieman, A.E. Goodwin, Treatments for Ich infections in channel catfish evaluated 419 under static and flow-through water conditions, North Am. J. Aquac. 63 (2001) 293-299.

420 [7] J. Sigh, K. Buchmann, Comparison of immobilization assays and enzyme-linked 421 immunosorbent assays for detection of rainbow trout antibody titres against 422 Ichthyophthirius multifiliis Fouquet, 1876. J. Fish Dis. 24 (2001) 49-51. 
423 [8] J.L. Maki, H.W. Dickerson, Systematic and cutaneous mucus antibody response of channel $424 \quad$ catfish immunized against the protozoan parasite. Clin. Diag. Lab. Immunol. 10 (2003) $425 \quad 876-881$.

426 [9] D.H. Xu, P.H. Klesius, R.A. Shelby, Immune responses and host protection of channel catfish, Ictalurus punctatus (Rafinesque), against Ichthyophthirius multifiliis after

[10] R.S. Hines, D.T. Spiral, Ichthyophthiriasis in the mirror carp Cyprinus carpio (L.) V. Acquired immunity, J. Fish Biol. 6 (1974) 373-8.

[11] H. Dickerson, T. Clark, Ichthyophthirius multifiliis: a model of cutaneous infection and immunity in fishes. Immunol. Rev. 166 (1998) 377-394.

[12] J. Sigh, T. Lindenstrøm, K. Buckmann, The parasite ciliate Ichthyophthirius multifiliis induces expression of immune relevant genes in rainbow trout, Oncorhynchus mykiss (Walbaum). J. Fish Dis. 27 (2004) 409-417.

[13] E. Bengtén, S.M. Quiniou, T.B. Stuge, T. Katagiri, N.W. Miller, L.W. Clem, G.W. Warr, M. Wilson, The IgH locus of the channel catfish, Ictalurus punctatus, contains multiple constant region gene sequences: different genes encode heavy chains of membrane and secreted IgD, J. Immunol. 169 (2002) 2488-2497.

[14] J.D. Hansen, E.D. Landis, R.B. Phillips, Discovery of a unique Ig heavy-chain isotype IgT in rainbow trout: implications for a distinctive B cell developmental pathway in teleosts fish, Proc. Nat. Acad. Sci. USA 102 (2005) 6919-6924.

[15] M.M. Olsen, P.W. Kania, R.D. Heinecke, K. Skjoedt, K.J. Rasmussen, K. Buchmann, Cellular and humoral factors involved in the response of rainbow trout gills to 
Ichthyophthirius multifiliis infections: Molecular and immunohistochemical studies. Fish \& Shellfish Immunol. 30 (2011) 859-869.

447 [16] M.L. Cross, R.A. Matthews, Localized leukocyte response to Ichthyophthirius multifiliis establishment in immune carp Cyprinus carpio L., Vet. Immunol. Immunopathol. 38 (1993) 341-358.

[17] R.D. Heinecke, K. Buchmann, Inflammatory response of rainbow trout Oncorhynchus mykiss (Walbaum, 1792) larvae against Ichthyophthirius multifiliis. Fish Shellfish Immun. 34 (2013) 521-528.

[18] L. von Gersdorff Jørgensen, E. Nemli, R. D. Heinecke, M.K. Raida, K. Buchmann, Immune relevant genes expressed in rainbow trout following immunisation with live vaccine against Ichthyophthirius multifiliis. Dis.Aquat. Org. 80 (2008)189-97.

[19] F. Zhao, Y.W. Li, H.J. Pan, C.B. Shi, X.C. Luo, A.X. Li, S.Q. Wu, Expression profiles of toll-like receptors in channel catfish (Ictalurus punctatus) after infection with Ichthyophthirius multifiliis, Fish Shellfish Immunol. 35 (2013) 993-997.

[20] D.H. Xu, P.H. Klesius, C.A. Shoemaker, Effect of immunization of channel catfish with inactivated trophonts on serum and cutaneous antibody titers and survival to Ichthyophthirius multifiliis. Fish Shellfish Immunol. 26 (2009) 614-618

[21] L. von Gersdorff Jørgensen, J. Sigh, P.W. Kania, L. Holten-Andersen, K. Buchmann, T. Clark, J.S. Rasmussen, K. Einer-Jensen, N. Lorenzen, Approaches towards DNA vaccination against a skin ciliate parasite in fish, PLoS ONE 7 (2012) e48129. doi:10.1371/journal.pone.0048129 
[22] J.W. Pridgeon, C.A. Shoemaker, P.H. Klesius, Identification and expression profile of multiple genes in the anterior kidney of channel catfish induced by modified live Edwardsiella ictaluri vaccination, Vet. Immunol. Immunopathol. 134 (2010) 184-198.

[23] X. Mu, J.W. Pridgeon, P.H. Klesius, Comparative transcriptional analysis reveals distinct expression patterns of channel catfish genes after the first infection and re-infection with Aeromonas hydrophila, Fish Shellfish Immunol. 35 (2013) 1566-1576.

[24] M.W. Pfaffl, A new mathematical model for relative quantification in real-time RT-PCR. Nucl. Acids Res. 29 (2001) 2002-2007.

[25] SAS Institute, SAS/Stat user's guide. $4^{\text {th }}$ ed., Cary, North Carolina, 1989.

[26] J. Kuby, (1994) Immunology. $2^{\text {nd }}$ ed., W.H. Freeman and Company, New York, 1994.

[27] E.S. Edholm, E. Bengten, J.L. Stafford, M. Sahoo, E.B. Taylor, N.W. Miller, M. Wilson, Identification of two $\mathrm{IgD}+\mathrm{B}$ cell populations in channel catfish, Ictalurus punctatus, J. Immunol. 185 (2010) 4082-4094.

[28] K. Chen, W. Xu, M. Wilson, B. He, N.W. Miller, E. Bengten, E.S. Edholm, P.A. Santini, P. Rath, A. Chiu, M. Cattalini, J. Litzman, J.B.B. Huang, B. Meini, A. Riesbeck, K. Cunningham-Rundles, C. Plebani, A.A. Cerutti, Immunoglobulin D enhances immune surveillance by activating antimicrobial, proinflammatory and B cell-stimulating programs in basophils, Nat. Immunol. 10 (2009) 889-898.

[29] U. Fischer, E.O. Koppang, T. Nakanishi, Teleost T and NK cell immunity, Fish Shellfish Immunol. 35(2013) 197-206. 
[30] X.M. Dan, T.W. Zhang, Y.W. Li, A.X. Li, Immune responses and immune-related gene expression profile in orange-spotted grouper after immunization with Cryptocaryon irritans vaccine, Fish Shellfish Immunol 34 (2013) 885-891.

[31] R. Savan, M. Sakai, Genomics of fish cytokines. Comp. Biochem. Physiol. Part D Genomics Proteomics 1 (2006) 89-101.

[32] T.P. Salazar-Mather, K.L. Hokeness, Cytokine and chemokine networks: pathways to antiviral defense, Curr. Top. Microbial. Immunol. 303 (2006) 29-46.

[33] S.F. Gonzalez, K. Buchmann, M.E. Nielsen, Real-time gene expression analysis in carp (Cyprinus carpio L.) skin: Inflammatory responses caused by the ectoparasite Ichthyophthirius multifiliis, Fish Shellfish Immunol. 22 (2007) 641-650.

[34] M. Claire, H. Holland, J.D. Lambris, The complement system in teleosts, Fish Shellfish Immunol. 12 (2002) 399-420.

[35] T. Kawai, S. Akira, The role of pattern-recognition receptors in innate immunity: update on Toll-like receptors. Nat. Immunol. 11 (2010) 373-384.

[36] H.W. Dickerson, A.L. Lohr, J.B. Gratzek, Experimental intraperitoneal infection of channel catfish, Ictalurus Punctatus (Rafinesque), with Ichthyophthirius multifiliis (Fouquet). J. Fish Dis. 8 (1985) 139-142.

[37] D.H. Xu, P.H. Klesius, C.A. Shoemaker, J.J. Evans, The early development of Ichthyophthirius multifiliis in channel catfish in vitro. J. Aquat. Anim. Health. 12 (2000) 290-296. 
507 Table 1. Primers used in qPCR for detection of target genes, including the size and location of amplicons and primer sequences.

\begin{tabular}{|c|c|c|c|c|c|}
\hline Gene & $\begin{array}{l}\text { GenBank } \\
\text { accession } \\
\text { number }\end{array}$ & $\begin{array}{l}\text { Amplicon } \\
\text { size (bp) }\end{array}$ & $\begin{array}{l}\text { Location of } \\
\text { amplicon }\end{array}$ & Forward Primer $\left(5^{\prime}-3^{\prime}\right)$ & Reverse Primer $\left(5^{\prime}-3^{\prime}\right)$ \\
\hline $\operatorname{IgM}$ & X79482 & 126 & $6434-6559$ & TGTGTGTGTGTGTGTGTGTGTT & CGGATGTCTTGGCTTGTTG \\
\hline $\operatorname{IgD}$ & AF363448 & 187 & $5646-5832$ & AAAGTGGCTCCCTGAATCTGT & ACTGGTGCTCTTCTCAACTGG \\
\hline $\operatorname{IgD} 2$ & AF363448 & 137 & $7671-7807$ & AGTTTACAGGAGGTGGGCAA & GGCCTATGGCATGTTCACAC \\
\hline IgD3 & AF363450 & 73 & $7988-8060$ & ACCTGTCAATCGGTGTTGGG & TCTTGCATTCCCCTCAGCAA \\
\hline CD4 & DQ435302 & 178 & $323-500$ & CCTCTGCGAACCCATCTTCA & AGGCAGGTCCAGATTCTTGC \\
\hline CD8 alpha & FJ804170 & 125 & $395-520$ & AGAAAGCATCCCCACTCTGC & CCGACCAAAGGACCAGAGAC \\
\hline MHC class I & AY008848 & 117 & $3622-3738$ & CAGAGGTGGTGTGTCATGCTA & CCTGGTTGGGTAACGTCTCTC \\
\hline MHC class II beta & U77598 & 90 & $442-531$ & CTGAGGAACGGGAAGGAGAT & CAGATGGGAGTGGACCTGAT \\
\hline $\mathrm{T}$ cell receptor alpha & JN097591 & 79 & $351-413$ & AGAAACGGGAGCCGTCAATTT & TTGTGAACTGTAAAGCGCGTG \\
\hline $\mathrm{T}$ cell receptor beta & AF410786 & 90 & $48-137$ & ACTCCAAGCACCAACTGTCA & ССТTTAGCCACACACACCAG \\
\hline Interleukin 1 beta type a & EE993591 & 219 & $630-848$ & AAAAATGGCCAGCCTGTATG & CAGCCCGGGTATTTAACTGA \\
\hline Interleukin 1 beta type $b$ & BM425330 & 193 & $224-416$ & GCCTCTTAGTATGCGCCAAG & AACCTTGTCTTGCAGGCTGT \\
\hline Inteferon $(\mathrm{IFN}-\gamma)$ & BM494266 & 179 & $8-186$ & CAGCAGTGACTTCAGCCAAA & GCCTCAGAGTACGCCATCAT \\
\hline TNF-a & CK413376 & 237 & $597-833$ & TTCTTAACGCGGGTGTTACC & GGGGGAAGGTTCTCTCATTC \\
\hline Complement factor $\mathrm{C} 3$ & BM438508 & 196 & $100-295$ & AGTTGAATACCGCTGCCAAC & СTCTCCATGCGCTGAGTACA \\
\hline Complement factor D & CK414026 & 242 & $526-767$ & AGGCAGAGGACAAAAAGCAA & TGGCTGACTTAGCTGCCAAT \\
\hline TLR1 & HQ677713 & 109 & $2853-2961$ & AGCCAAAGAAATGCCAACTG & TGAAGTCTCGTTCGTGGTGA \\
\hline TLR9 & HQ677720 & 110 & $5034-5143$ & GGAGGAACGGGACTGGATAC & AAGCACAGCCACCCTGATTA \\
\hline $18 \mathrm{~S}$ rRNA & BE469353 & 220 & $236-455$ & ATGGCCGTTCTTAGTTGGTG & TAGGTAGCACACGCTGATCG \\
\hline
\end{tabular}


508 Table 2. Antibody titers of immobilization assay (Immob) and enzyme-linked immunosorbent 509 assay (ELISA) against Ichthyophthirius multifiliis in serum of channel catfish at different time510 points post immunization. Within a column for each assay, means followed by the same lower 511 case letter are not significantly different $(\mathrm{P}>0.05)$.

512 Sampling time

514 Assay Groups Hour 4 Day $1 \quad$ Day 2 Day 6 Day $10 \quad$ Day 20 515 516 517 518 519 Control $\quad 26.7 \pm 6.7^{\mathrm{a}} 16.7 \pm 3.3^{\mathrm{a}}$ $6.7 \pm 6.7^{\mathrm{a}} 20 \pm 0^{\mathrm{a}}$ $26.7 \pm 3.3^{\mathrm{a}} \quad 20 \pm 0^{\mathrm{a}}$ Immune $\quad 18 \pm 2^{\mathrm{a}} \quad 26 \pm 6^{\mathrm{a}}$ $8.0 \pm 4.9^{\mathrm{a}} 64 \pm 9.8^{\mathrm{b}} \quad 512 \pm 78^{\mathrm{b}} \quad 1280 \pm 0^{\mathrm{b}}$ ELISA Control $\quad 10 \pm 0^{a}$ $10 \pm 0^{\mathrm{a}}$ $10 \pm 0^{\mathrm{a}} \quad 10 \pm 0^{\mathrm{a}}$ $10 \pm 0^{\mathrm{a}} \quad 10 \pm 0^{\mathrm{a}}$

Immune $\quad 10 \pm 0^{\mathrm{a}} \quad 10 \pm 0^{\mathrm{a}}$

$10 \pm 0^{\mathrm{a}}$
$12 \pm 2^{a}$ $74 \pm 6.5^{b} 1152 \pm 128^{b}$ 
521 Table 3. Survival and mean days to death of immunized channel catfish following challenge

522 with theronts of Ichthyophthirius multifiliis at the dose of 40,000 theronts per fish for one hour

523 and observed for 21 days. Infection level was determined 6 days post challenge. Twenty fish

524 were used for each immunization group.

525

526

$527 \quad$ Groups

Infection

Number of

Survival

Mean days

level*

dead fish

(\%)

to death

528

529 Control

Heavy

20

0

5.6

530

light

1

95

14

531

$532 *$ Infection level, light $\left(<50\right.$ trophonts fish $\left.^{-1}\right)$, mild $\left(50-100\right.$ trophonts fish $\left.{ }^{-1}\right)$ and heavy

533 infection (>100 trophonts fish $\left.{ }^{-1}\right)$.

534

535

536

537

538 
FIGURES

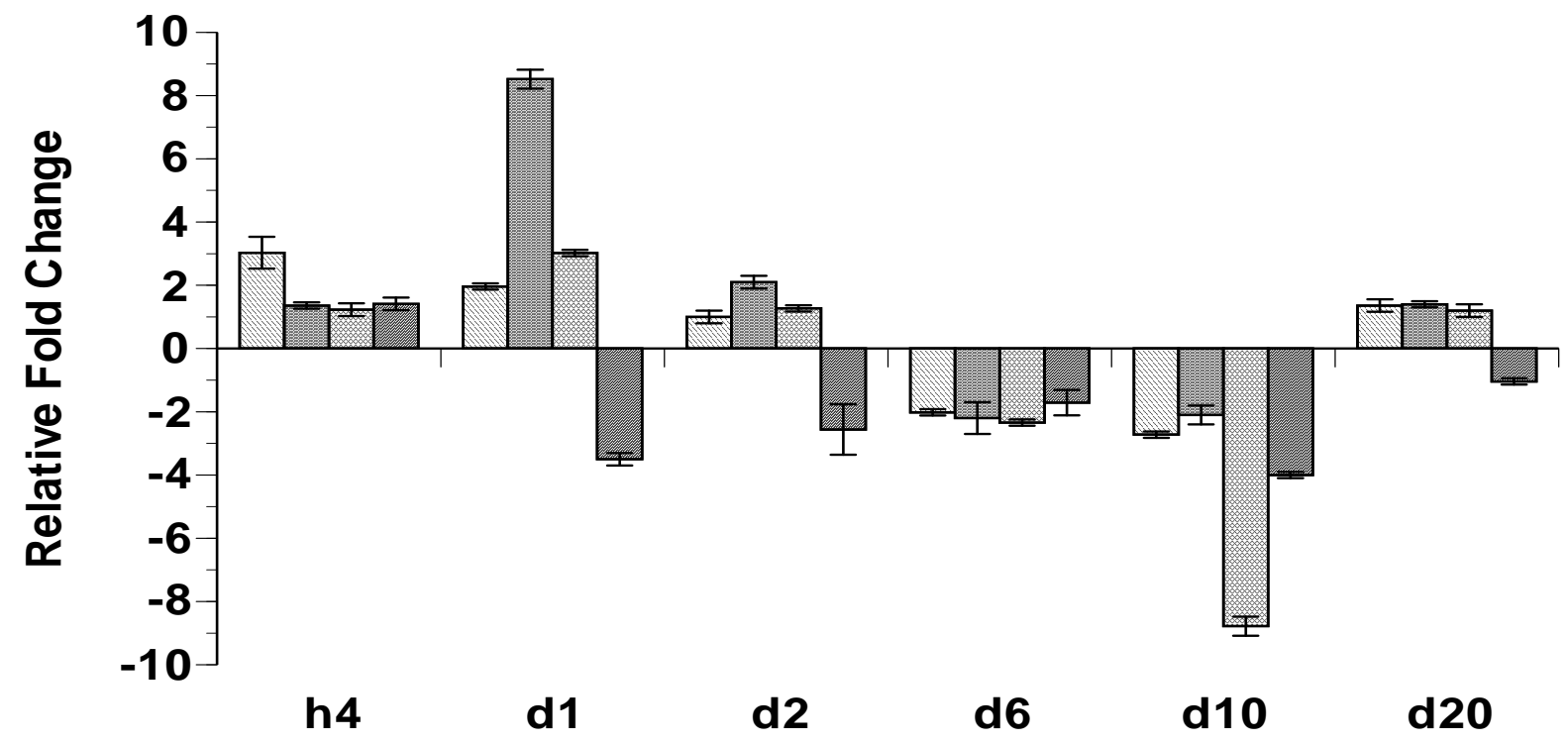

544 Fig 1. Expression of immunoglobulin heavy chain genes in the head kidney of channel catfish at 545 different time points post immunization of Ichthyophthirius multifiliis. Data are presented as 546 relative fold change of genes from immunized fish compared with mock-immunized control fish.

547 IgM: immunoglobulin M, IgD: both membrane bound and secreted form of immunoglobulin D, $548 \operatorname{IgD2}$ : membrane bound $\operatorname{IgD}$, IgD3: secreted form of $\operatorname{IgD}$. 

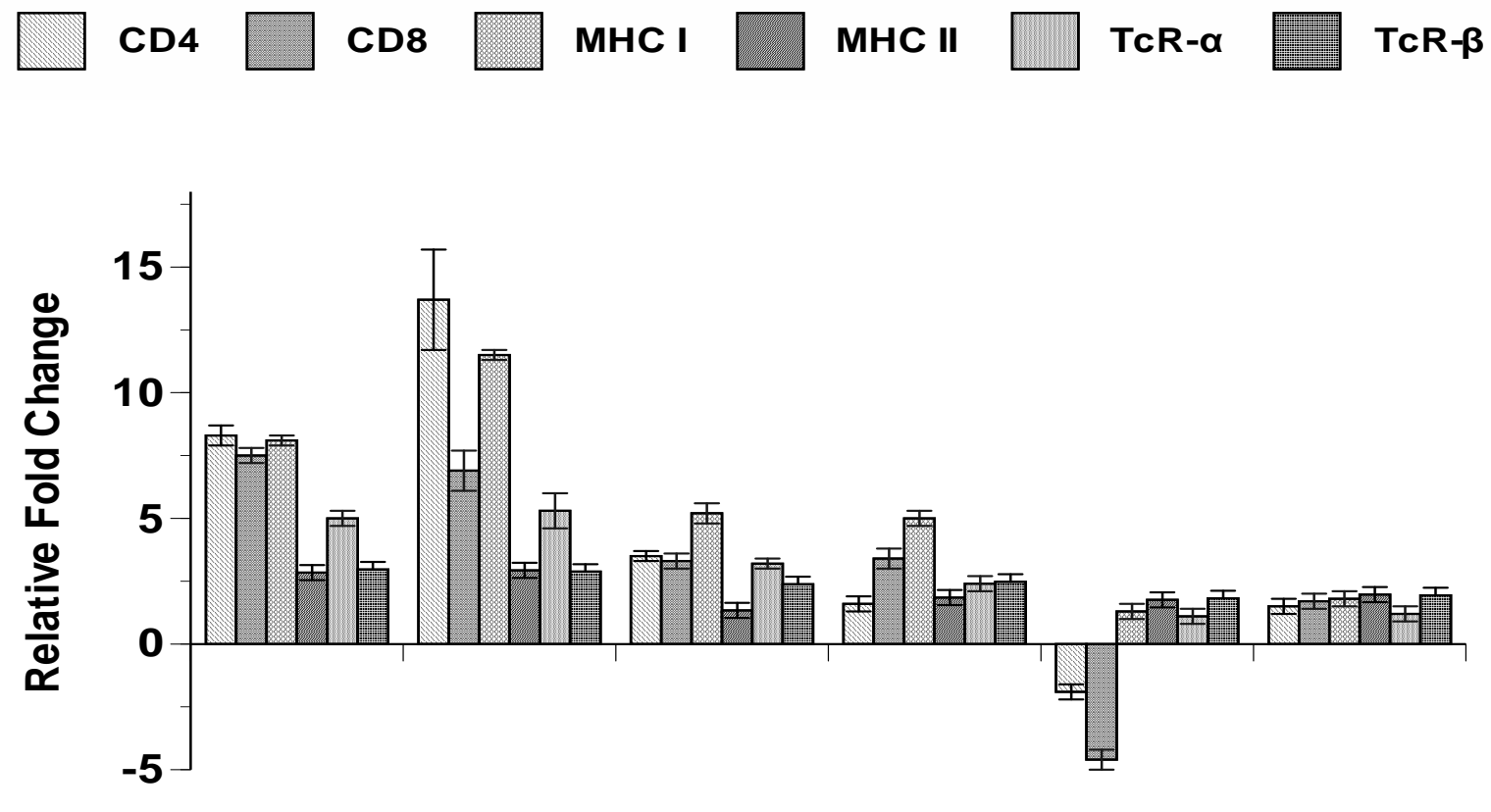

h4 d1

d2

d6

d10

d20

Fig 2. Expression of immune cell receptor genes in the head kidney of channel catfish at

558 different time-points post immunization of Ichthyophthirius multifiliis. Data are presented as

559 relative fold change of genes from immunized fish compared with mock-immunized control fish.

560 CD: cluster of differentiation, MHC: major histocompatibility complex, TcR: T cell receptor. 


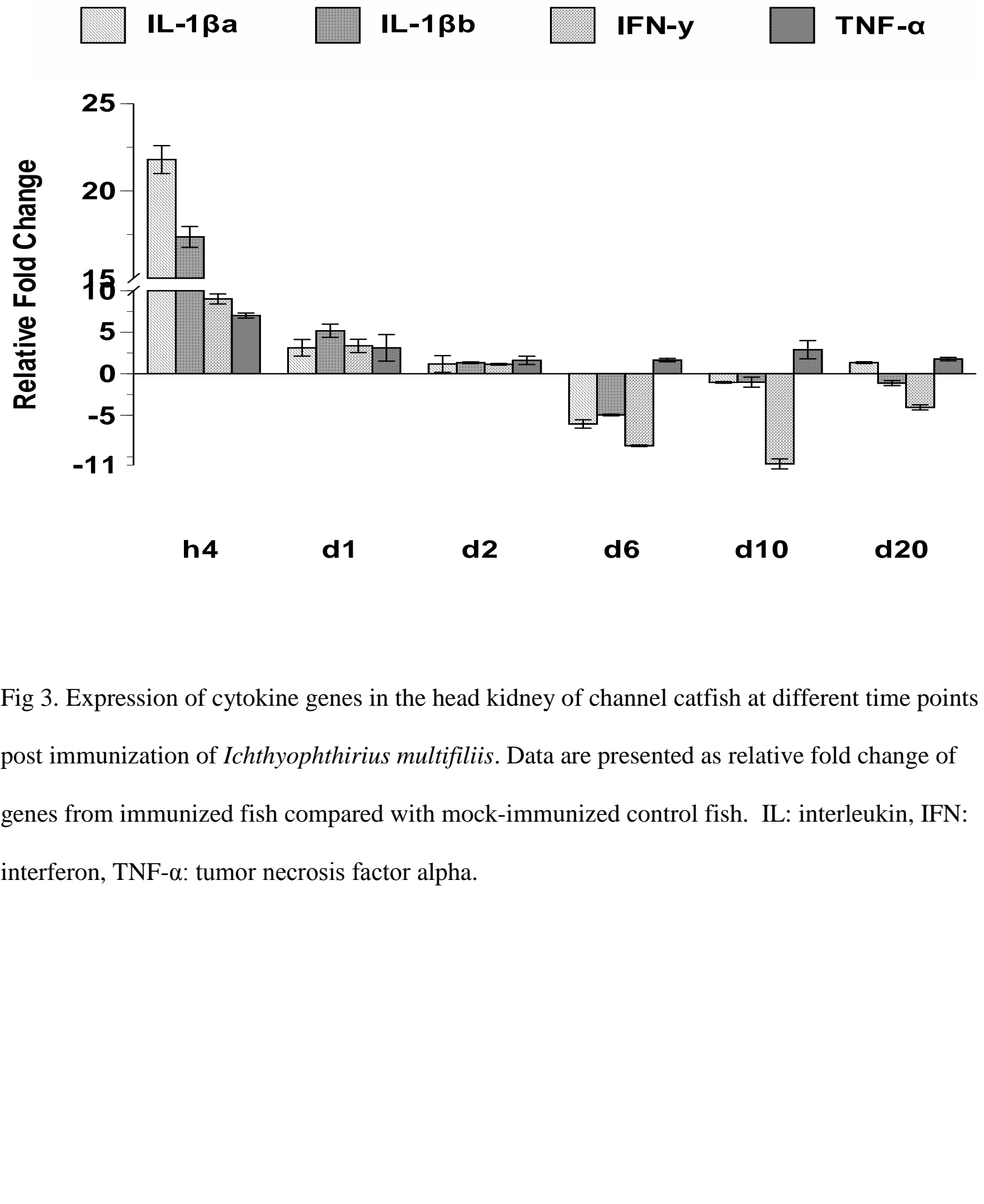



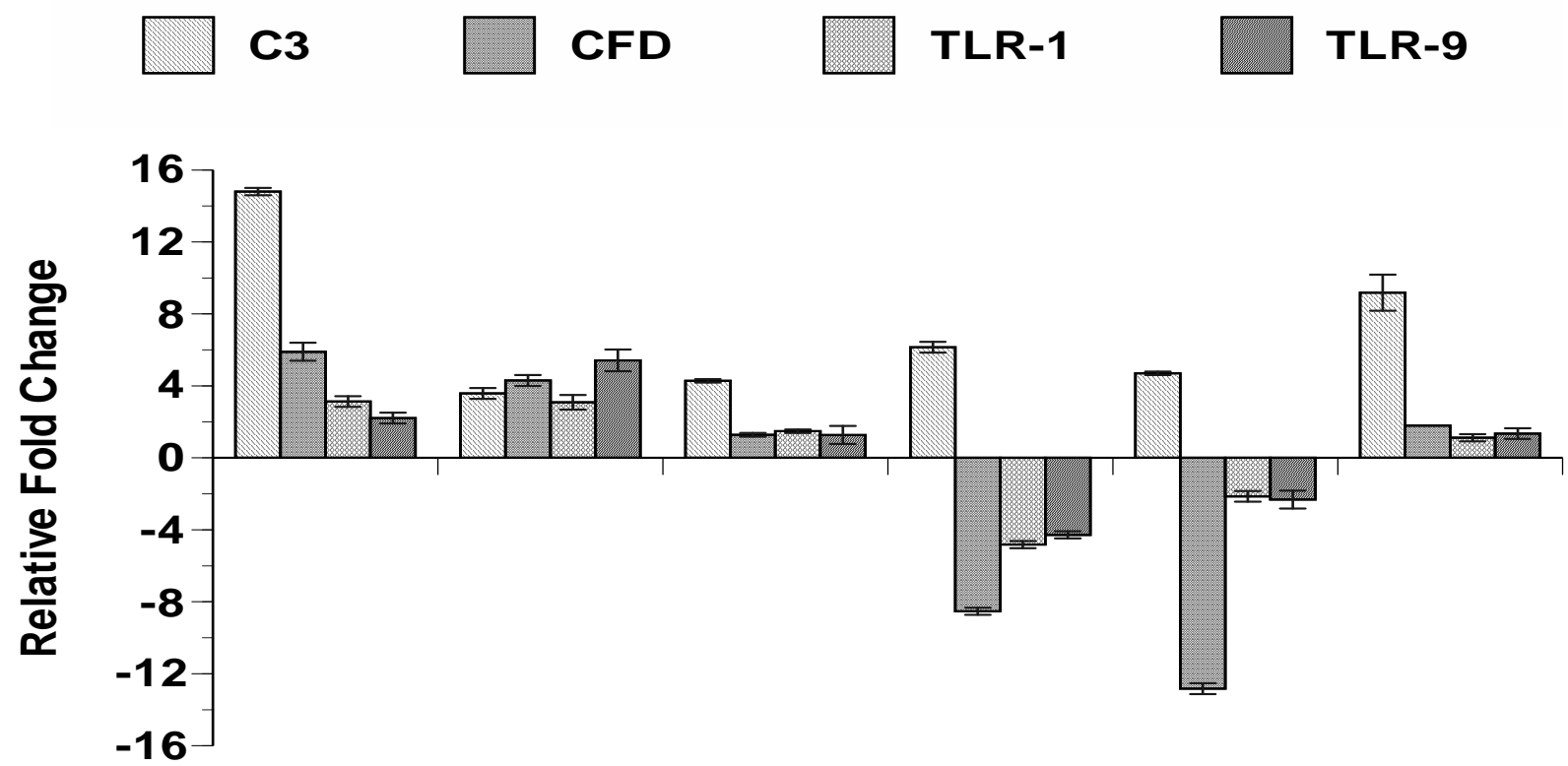

590 Fig 4. Expression of complement factor and toll-like receptor genes in the head kidney of

591 channel catfish at different time points post immunization of Ichthyophthirius multifiliis. Data

592 are presented as fold changes of genes from immunized fish compared with mock-immunized

593 control. C3: complement component 3, CFD: complement factor D, TLR: toll-like receptor. 